\title{
UJI AKTIVITAS ANTIBAKTERI DARI SEDIAAN KRIM EKSTRAK ETANOL HERBA TUMBUHAN BALSEM (Polygala paniculata L.) TERHADAP BAKTERI Propionebacterium acnes PENYEBAB JERAWAT
}

\author{
Helen Anjelina Simanjuntak ${ }^{1 *}$ dan Kasta Gurning ${ }^{1)}$ \\ 1)Program Studi Farmasi, Sekolah Tinggi Ilmu Kesehatan Senior Medan, Medan \\ e-mail:helenanjelinas@gmail.com
}

\begin{abstract}
Acne is a skin disorder that occurs due to chronic inflammation, which is triggered by the growth of bacteria Propionibacterium acnes. The Balm plant (Polygala paniculata L.) is a small shrub originating from Indonesia. The purpose of this research is to determine the antibacterial activity of the formulation of a cream extract of the herbal ethanol extracts of the balm to the growth of bacteria Propionebacterium acnes. This research is an experimental study with five dosage formulations where the used concentration of extract consists of $0 \%(\mathrm{~F} 1), 2 \%(\mathrm{~F} 2), 4 \%(\mathrm{~F} 3), 6 \%(\mathrm{~F} 4)$, VitaCid as a positive control. The testing of antibacterial activity conducted by the CUP-plate technique method. Results showed that the extract of the balm plant in the preparation of cream could inhibit the growth of Propionibacterium acnes, visible with the formation of clear zones. The F1 cream preparations and F2 have stable and F3 categories, F4 has a dominant type.
\end{abstract}

Keywords: Antibacterial, Cream, Extract, Herb Balm, Polygala paniculata L.

\begin{abstract}
Abstrak
Jerawat adalah penyakit kulit yang terjadi akibat adanya peradangan menahun yang dipicu oleh pertumbuhan bakteri Propionebacterium acnes. Tumbuhan balsem (Polygala paniculata L.) merupakan semak kecil yang berasal dari Indonesia. Tujuan penelitian ini untuk mengetahui aktivitas antibakteri dari formulasi sediaan krim ekstrak etanol herba tumbuhan balsem terhadap pertumbuhan bakteri Propionebacterium acnes. Penelitian ini merupakan penelitian eksperimental dengan lima formulasi sediaan krim dimana konsentrasi ekstrak yang di pakai terdiri dari $0 \%$ (F1), 2\% (F2), 4\% (F3), 6\% (F4), VitaCid sebagai kontrol positif. Pengujian aktivitas antibakteri dilakukan dengan Metode Cup-plate technique. Hasil menunjukkan bahwa ekstrak tumbuhan balsem dalam sediaan krim memiliki kemampuan menghambat pertumbuhan Propionibacterium acnes, terlihat dengan terbentuknya zona bening. Sediaan krim F1 dan F2 memiliki kategori Kuat dan F3, F4 memiliki kategori sangat kuat.
\end{abstract}

Kata Kunci: Antibakteri, Krim, Ekstrak, Tumbuhan balsem (Polygala paniculata L.)

\section{PENDAHULUAN}

Acne vulgaris yang dikenal awam dengan jerawat adalah penyakit kulit yang terjadi akibat adanya peradangan menahun. Peradangan dipicu oleh bakteri Propionibacterium acnes, Staphylococcus epidermidis, dan Staphylococcus aureus (Wasiaatmadja, 1997). Mekanisme terjadinya jerawat adalah bakteri Propionibacterium acnes merusak stratum corneum dan stratum germinat dengan cara menyekresikan bahan kimia yang menghancurkan dinding pori. Kondisi ini dapat menyebabkan inflamasi. Asam lemak dan minyak kulit tersumbat dan mengeras. Jika jerawat disentuh maka inflamasi akan meluas sehingga padatan asam lemak dan minyak kulit yang mengeras akan membesar (Rusli dkk., 2016). 
Propionibacterium acnes merupakan bagian flora kulit normal, kadang-kadang bakteri ini muncul dalam biakan darah dan harus dibedakan sebagai suatu pencemarbiakan atau penyebab sebenarnya dari penyakit. Propionibacterium acnes merupakan difteroid anaerob yang biasanya menetap pada kulit normal. Bakteri ini ikut serta dalam patogenesis jerawat dengan menghasilkan lipase, yang memecahkan asam lemak bebas dari lipid kulit. Bakteri ini mampu mengaktifkan dan melengkapi kemampuannya untuk memetabolisme trigliserida sebaceous menjadi asam lemak (Kumar, 2007). Propionibacterium acnes menghasilkan komponen aktif seperti lipase, protease, hialuronidase, dan faktor kemotaktik yang menyebabkan inflamasi. Lipase berperan dalam menghidrolisis trigliserida sebum menjadi asam lemak bebas yang berperan dalam menimbulkan hyperkeratosis, retensi dan pembentukan mikrokomedo (Afriyanti, 2015).

Salah satu alternatif dalam pengobatan jerawat adalah dengan terapi antibiotik seperti klindamisin, eritromisin, atau tetrasiklin. Terapi ini cenderung menyebabkan peningkatan terjadinya infeksi saluran nafas atas bila dibandingkan dengan pasien berjerawat tanpa terapi antibiotik (Margolis dkk., 2005). Sehingga perlu dilakukan inovasi seperti penggunaan bahan alam sebagai krim salah satunya adalah tumbuhan balsem (Polygala paniculata L.).

Tumbuhan balsem (Polygala paniculata L.) termasuk ke dalam family Polygalaceae merupakan semak kecil yang bersal dari Indonesia. Family Polygalaceae terdiri dari 725 spesies didistribusikan di seluruh dunia (Tizziani et al., 2017). Secara tradisional tumbuhan ini digunakan dalam mengobati penyakit seperti asma, bronchitis, radang sendi, sakit perut, diare, gangguan ginjal, antipsikotik, antitumor, antiinflamasi, antimikroba dan antispasmodic (Lapa et al., 2007). Herba tumbuhan balsem berpotensi dalam bidang farmasi seperti bahan obat sitotoksik, antijamur dan antibakteri (Rijai, 2013).

Bentuk sediaan kosmetik yang sering digunakan untuk perawatan kulit adalah sediaan krim (Fitriansyah dan Dolih, 2014). Krim adalah sediaan setengah padat yang mengandung air tidak kurang dari 60\% dan dimaksudkan untuk pemakaian luar. Selain itu, krim merupakan bentuk sediaan topikal dengan bentuk setengah padat yang cocok untuk pengobatan jerawat. Penggunaan krim lebih disukai karena krim lebih mudah menyebar dengan rata dan lebih mudah dibersihkan serta dicuci (Atmoko dan Amon, 2014).

Berdasarkan literature di atas, maka peneliti tertarik untuk melakukan penelitian tentang uji aktivitas antibakteri dari sediaan krim ekstrak etanol herba tumbuhan balsem terhadap bakteri Porpionebacterium acnes penyebab jerawat. Penelitian ini bertujuan untuk mengetahui aktivitas antibakteri dari sediaan krim ekstrak etanol herba tumbuhan balsem terhadap bakteri Porpionebacterium acnes penyebab jerawat.

\section{METODE}

Metode penelitian ini secara eksperimental dengan tahapan penelitian, yaitu pembuatan ekstrak dengan metode maserasi, skrining fitokimia, pembuatan sediaan krim, dan uji aktivitas antibakteri dengan metode Cup-plate technique.

Alat yang digunakan adalah timbangan, mortir dan stamper, gelas ukur, beaker glass, sudip, kertas perkamen, spatula, cawan porselen, jarum ose, lampu spritus, lemari pendingin, oven, autoklaf, tabung reaksi, rak tabung, kasa steril, jangka sorong gitital, cawan petri, botol sampel, corck born dan rotary evaporator.

Bahan yang digunakan dalam penelitian ini adalah NA (Nutrient Agar), MHA (Mueller Hinton Agar), akuades, bakteri Propionibacterium acnes, etanol 96\%, herba tumbuhan balsem (Polygala paniculata L.), larutan standar Mc. Farland no. 1, pereaksi dragendrof, pereaksi lieberman-burchard, pereaksi Mayer, $\mathrm{FeCl}_{3} 1 \%$, serbuk magnesium, asam klorida $2 \mathrm{~N}, \mathrm{NaOH} 10 \%, \mathrm{H}_{2} \mathrm{SO}_{4}$, KI, dan asam asetat anhidrat. 


\section{Prosedur Kerja}

a. Persiapan sampel

Sampel tumbuhan segar (semua bagian tumbuhan) balsam Polygala paniculata L. diambil dan dikumpulkan dari Desa Talang Danto, Kecamatan Tapung Hulu, Kabupaten Kampar, Provinsi Riau. Sampel dibersihkan dengan dicuci diair mengalir, ditiriskan dan dikeringkan diruangan terbuka. Kemudian sampel di haluskan dengan blender sehingga membentuk serbuk simplisia.

\section{b. Identifikasi Sampel}

Identifikasi tumbuhan dilakukan di Herbarium Medanense, Laboratorium Herbarium, Departemen Biologi, Fakultas Matematika dan Ilmu Pengetahuan Alam (FMIPA) Universitas Sumatera Utara.

\section{c. Pembuatan Ekstrak}

Sebanyak 1000 g serbuk simplisia dimaserasi dengan etanol $96 \%$ selama 5 hari pada suhu kamar dan sesekali diaduk. Setelah 5 hari, hasil maserasi disaring. Kemudian filtrat dipekatkan menggunakan rotary evaporator pada suhu $40^{\circ} \mathrm{C}$ untuk mendapatkan ekstrak kasar.

\section{d. Skrining Fitokimia \\ Uji Alkaloid}

Disiapkan tiga tabung reaksi dan dimasukkan 1 gram simplisia, kemudian ditambahkan reagen dragendorff, pada tabung kedua ditambahkan reagen wagner, pada tabung ketiga ditambahkan reagen mayer dan amati perubahan yang terjadi. Hasil positif bila pada tabung pertama (reagen dragendorff) menghasilkan endapan merah, pada tabung kedua (reagen wagner) menghasilkan endapan kecoklatan, dan pada tabung ketiga (reagen mayer) menghasilkan endapan putih.

\section{Uji Flavonoid}

Simplisia ditimbang $1 \mathrm{~g}$, dimasukkan kedalam tabung reaksi dan ditambahkan dengan 20 $\mathrm{mL}$ air panas sampai terendam, lalu dipanaskan kemudian disaring. Filtrat ditambahkan 0,1 gram serbuk Magnesium, $1 \mathrm{~mL}$ asam klorida p, $2 \mathrm{~mL}$ amil alkohol di kocok dan dibiarkan memisah. Terbentuknya warna kuning, hijau, merah atau jingga menunjukan adanya flavonoid.

\section{Uji Saponin}

Simplisia ditimbang $1 \mathrm{~g}$, dimasukkan kedalam tabung reaksi dan ditambahkan dengan air panas sebanyak $5 \mathrm{~mL}$ sampai semua ekstrak terendam dan dikocok kuat-kuat selama 10 detik. Terdapat busa setelah pengocokan setinggi $1-10 \mathrm{~cm}$, busa ditunggu selama 10 menit dan tetap konstan maka ekstrak positif mengandung senyawa saponin.

\section{Uji Tanin}

Simplisia ditimbang 1 gram, dimasukkan kedalam tabung reaksi dan ditambahkan $3 \mathrm{~mL}$ air hangat kemudian disaring. Ekstrak diujikan dengan $1-5$ tetes $\mathrm{FeCl}_{3} 1 \%$ menimbulkan warna hijau, merah, ungu, biru, atau hitam yang kuat menunjukkan adanya senyawa golongan tanin.

\section{Uji Steroid dan Triterpenoid}

Simplisia ditimbang sebanyak $1 \mathrm{~g}$, dimaserasi dengan $20 \mathrm{~mL}$ n-heksan selama 2 jam, disaring, filtrat diuapkan dan sisanya ditambahkan 20 tetes pereaksi Liebermann Burchard (asam asetat anhidrat dan asam sulfat pekat). Sampel yang mengandung senyawa golongan 
steroid akan berubah warna menjadi hijau kebiruan. Sedangkan senyawa golongan triterpenoid akan berubah warna membentuk cincin coklat atau violet.

\section{Pembuatan Formulasi Sediaan Krim}

Adapun konsentrasi ekstrak tumbuhan balsem yang digunakan dalam sediaan krim terdiri dari $0 \%(\mathrm{~F} 1), 2 \%(\mathrm{~F} 2), 4 \%(\mathrm{~F} 3)$, dan 6\% (F4), dapat dilihat pada Tabel 1.

Tabel 1. Formulasi Sediaan Krim Ekstrak Etanol Herba Tumbuhan Balsem (Polygala paniculata L.)

\begin{tabular}{lcccccc}
\hline \multirow{2}{*}{ Bahan } & Satuan & \multicolumn{4}{c}{ Kosentrasi \% } & \multirow{2}{*}{ Kegunaan } \\
\cline { 3 - 6 } & & F1 & F2 & F3 & F4 & \\
\hline Ekstrak tumbuhan balsem & Gram & 0 & 2 & 4 & 6 & Zat aktif \\
Asam stearat & Gram & 12 & 12 & 12 & 12 & Pengemulsi \\
Setil alkohol & Gram & 0,5 & 0,5 & 0,5 & 0,5 & Pengental \\
TEA & $\mathrm{mL}$ & 1 & 1 & 1 & 1 & Pengemulsi \\
Metil paraben & Gram & 0,1 & 0,1 & 0,1 & 0,1 & Pengawet \\
Propil paraben & Gram & 0,5 & 0,5 & 0,5 & 0,5 & Pengawet \\
Gliserin & $\mathrm{mL}$ & 2 & 2 & 2 & 2 & Humektan \\
Akuades add & $\mathrm{mL}$ & 100 & 100 & 100 & 100 & Pelarut \\
\hline
\end{tabular}

\section{Cara Pembuatan Krim:}

Fase minyak (asam stearat, setil alkohol ) dilelehkan diatas penangas air (massa 1). Fase air (TEA, Metil paraben, Propil paraben dan gliserin dan air) dicampur kemudian dipanaskan diatas penangas air (massa 2). Campurkan massa 1 dan 2 sedikit demi sedikit kemudian gerus sampai terbentuk massa krim. Dimasukkan ekstrak herba tumbuhan balsem lalu gerus sampai halus dan homogen kemudian masukan kedalam wadah (Erawaty dkk., 2015).

\section{Pengujian Aktivtas Antibakteri Metode Cup-plate technique}

Sebanyak 38 gram media MHA dilarutkan dalam $1000 \mathrm{ml}$ akuades. Dipanaskan sampai homogen. Kemudian di sterilkan di autoklaf. Media MHA didinginkan sampai 40 $50^{\circ} \mathrm{C}$, kemudian dituangkan kedalam cawan petri lalu didiamkan hingga memadat. Suspensi bakteri Propionebacterium acnes yang distandarkan dengan Mc. Farland no.1. Cutton bud dicelupkan kedalam suspensi bakteri kemudian diusapkan pada media. Dibuat lubang sumuran pada media agar dengan menggunakan corck borner kemudian beri tanda untuk masing-masing lubang sumuran. Ditimbang masing-masing sediaan sebanyak $50 \mathrm{mg}$, kemudian dimasukkan kedalam masing-masing lubang sumuran yang telah diberi tanda. Diinkubasi selama 1 x 48 jam pada suhu $37^{\circ} \mathrm{C}$. Kemudian diukur diameter zona bening dengan menggunakan jangka sorong (Rusli dkk., 2016).

\section{HASIL DAN PEMBAHASAN}

\section{Skrining Fitokimia}

Fitokimia merupakan suatu metode analisis awal untuk meneliti kandungan senyawa kimia yang terdapat pada tumbuhan (Vicker dan Vickery. 1981 dalam Nurrani dkk., 2014). Berdasarkan Tabel 2. dapat dilihat bahwa tumbuhan balsem memiliki golongan senyawa metabolit sekunder terdiri dari alkaloid, flavonoid, tanin, saponin, dan triterpenoid/steroid. Hal ini sejalan dengan penelitian Rijai (2013), menjelaskan bahwa herba tumbuhan balsem memiliki potensi dalam bidang kefarmasian karena mengandung metabolit sekunder seperti alkaloid, flavonoid, tannin, saponin dan steroid. Hasil skrining fitokimia dari herba tumbuhan balsem (Polygala paniculata L.) dapat dilihat pada Tabel 2. 
Tabel 2. Skrining Fitokimia Herba Tumbuhan Balsem (Polygala paniculata L.)

\begin{tabular}{lcc}
\hline \multicolumn{1}{c}{ Golongan Senyawa Metabolit } & \multicolumn{2}{c}{ Hasil Skrining Fitokimia } \\
\cline { 2 - 3 } \multicolumn{1}{c}{ Sekunder } & Simplisia & Ekstrak \\
\hline Alkaloid & + & + \\
Flavonoid & + & + \\
Tanin & + & + \\
Saponin & + & + \\
Triterpenoid / Steroid & + & + \\
\hline
\end{tabular}

\section{Diameter Zona Hambat}

Hasil diameter zona hambat dari sediaan krim ekstrak etanol herba tumbuhan balsem (Polygala paniculata L.) dapat dilihat pada Tabel 3 dan Gambar 1.

Tabel 3. Hasil diameter zona hambat dari sediaan krim ekstrak etanol herba tumbuhan balsem (Polygala paniculata L.)

\begin{tabular}{|c|c|c|c|c|c|}
\hline \multirow[t]{2}{*}{ Formula Krim } & \multicolumn{3}{|c|}{ Diameter zona hambat (mm) } & \multirow[t]{2}{*}{ Rata-rata } & \multirow[t]{2}{*}{ Kategori } \\
\hline & U1 & U2 & U3 & & \\
\hline F1 & 16,8 & 15,4 & 17,7 & 16,63 & Kuat \\
\hline $\mathrm{F} 2$ & 17 & 18,8 & 19,7 & 18,50 & Kuat \\
\hline F3 & 27,7 & 26,3 & 27,6 & 27,20 & Sangat kuat \\
\hline F4 & 27,2 & 29,3 & 31,7 & 29,40 & Sangat kuat \\
\hline Vitacid & 22,4 & 21,7 & 23 & 22,37 & Sangat kuat \\
\hline
\end{tabular}
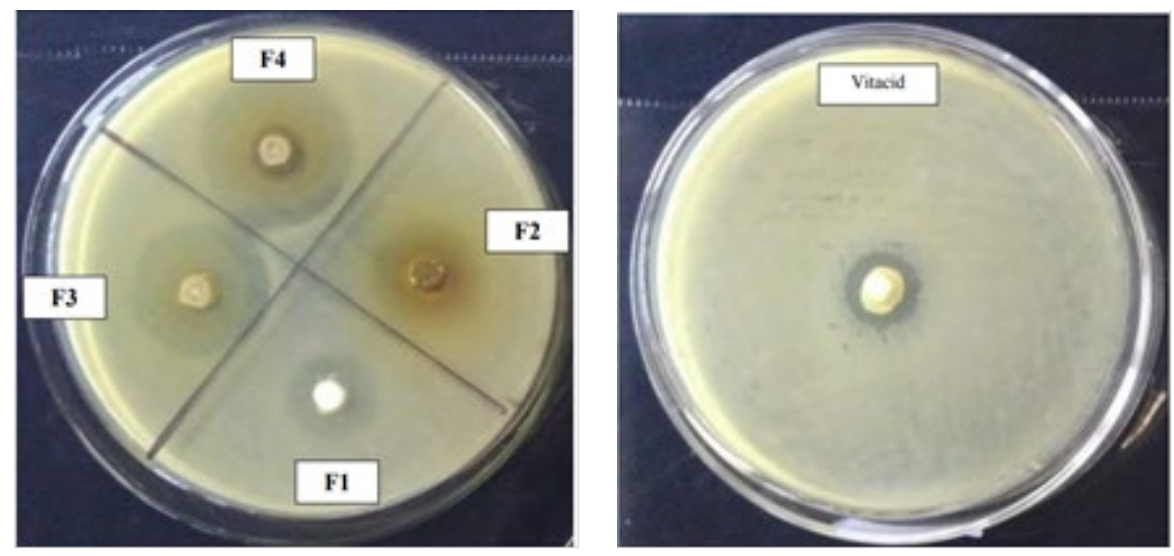

Gambar 1. Diameter Zona Hambat Sediaan Krim Ekstrak Herba Tumbuhan Balsem (Polygala paniculata L.), F1 (Basis Krim), F2 (2\%), F3 (4\%), F4 (6\%), dan Vitacid sebagai kontrol positif.

Berdasarkan Tabel 3 dan Gambar 1 dapat dilihat bahwa semakin tinggi kandungan ekstrak pada sediaan krim menunjukkan bahwa semakin tinggi diameter zona hambat pada bakteri Propionebacterium acnes. Zona hambat ditunjukkan dengan adanya zona bening yang menyimpulkan bahwa adanya daerah hambatan pertumbuhan bakteri (Cappucino, 2008). Pada sediaan krim F1 dan F2 termasuk kedalam kategori kuat, sedangkan F3 dan F4 termasuk ke dalam kategori sangat kuat. Menurut Davis dan Stout (2009), menyatakan bahwa daya hambat bakteri dengan diameter $\leq 5 \mathrm{~mm}$ menunjukkan kategori lemah, $5-10 \mathrm{~mm}$ menunjukkan kategori sedang, $10-20 \mathrm{~mm}$ menunjukkan kategori kuat, dan $\geq 20 \mathrm{~mm}$ menunjukkan kategori sangat kuat.

Sedian krim F1 tidak diberikan ekstrak herba tumbuhan balsem namun menunjukkan adanya aktivitas antibakteri terhadap bakteri Propionebacterium acnes, hal ini terjadi karena pada sediaan krim terdapat komponen-komponen yang berperan sebagai pengawet seperti metil paraben dan propil paraben. Metil paraben dan propil paraben diperlukan dalam 
formulasi sediaan untuk mencegah kontaminasi mikroba karena tingginya kandungan air pada sediaan (Rowe dan Owen, 2006 ; Sulastri dan Anis, 2016).

Sediaan krim F3, dan F4 yang diberikan formulasi ekstrak herba tumbuhan balsem (Polygala paniculata L.) menunjukkan adanya aktivitas antibakteri dilihat dengan adanya diameter zona hambat yang semakin tinggi pada formulasi. Hal ini disebabkan karena adanya senyawa kimia yang terdapat pada ekstrak herba tumbuhan balsem yang berperan sebagai antibakteri seperti alkaloid, flavonoid, saponin, steroid/triterpenoid, dan tannin.

Senyawa alkaloid memiliki peran sebagai antibakteri dengan cara mengganggu komponen penyusun peptidoglikan pada dinding sel bakteri dan sebagai akselerator dalam enzim topoisomerase dalam penghambat DNA sel bakteri (Wu et al. 2013 dalam Simanjuntak, 2020). Senyawa flavonoid merupakan turunan fenol yang dapat menyebabkan denaturasi dan koagulasi protein sel bakteri, dimana senyawa flavonoid memanfaatkan perbedaan kepolaran antara lipid penyusun sel bakteri dengan gugus alkohol pada senyawa flavonoid (Suryani dkk., 2019).

Senyawa tanin merupakan senyawa aktif metabolit sekunder yang diketahui mempunyai beberapa khasiat yaitu antibakteri. Tanin dapat mengambat pertumbuhan mikroba dengan mekanisme merusak dinding sel mikroba dan membentuk ikatan protein fungsional sel mikroba. Tanin juga merupakan senyawa yang bersifat lipofilik sehingga mudah terikat pada dinding sel dan mengakibatkan kerusakan dinding sel (Sudira, dkk., 2011). Senyawa tannin juga dapat mengambat enzim reverse transcriptase dan DNA topoisomerase sehingga sel bakteri tidak terbentuk (Septiana, dkk., 2016).

Senyawa saponin memiliki efek antibakteri dan antijamur dengan mengganggu gugus monosakarida dan turunannya (Cheeke et al., 2003; Simanjuntak dan Megawati, 2019). Saponin bersifat polar, kepolaran senyawa inilah yang mengakibatkan senyawa ini lebih mudah menembus dinding bakteri (Lusiana, 2016 dalam Kono dkk., 2018). Mekanisme kerja saponin sebagai antibakteri yaitu dapat menyebabkan kebocoran protein dan enzim dari dalam sel (Madduluri et al., 2013). Saponin memiliki zat aktif permukaannya mirip detergen, akibatnya saponin dapat menurunkan tegangan permukaan dinding sel bakteri dan merusak kelangsungan hidup bakteri (Suryani dkk., 2019). Saponin berdifusi melalui membran sel dan dinding sel yang rentan kemudian mengikat membran sitoplasma sehingga mengganggu dan mengurangi kestabilan membran sel. Hal ini menyebabkan sitoplasma bocor keluar dari sel yang mengakibatkan kematian sel (Harbone, 1987).

Senyawa terpenoid sebagai antibakteri adalah bereaksi dengan porin (protein transmembran) pada membran luar dinding sel bakteri, membentuk ikatan polimer yang kuat sehingga mengakibatkan rusaknya porin. Rusaknya porin yang merupakan pintu keluar masuknya senyawa akan mengurangi permeabilitas dinding sel bakteri akan kekurangan nutrisi, sehingga pertumbuhan bakteri terhambat atau mati (Yaqin, 2014 dalam Suryani dkk., 2019).

\section{KESIMPULAN}

Sedian krim ekstrak etanol herba tumbuhan balsem (Polygala paniculata L.) efektif dalam menghambat pertumbuhan bakteri Propionebacterium acnes penyebab jerawat.

\section{DAFTAR PUSTAKA}

Afriyanti RN. 2015. Acne vulgaris Pada Remaja. Medical Jurnal of Lampung University. Vol $4(5): 1-3$.

Atmoko AD., dan Anom P. 2014. Formulasi Bentuk Sediaan Krim Ekstrak Daun Sirih (Piper betle Linn) Hasil Isolasi Metode Maserasi Etanol 90\%. Indonesian Journal on Medical Science. Vol. 1(2). 
Cappucino, James G., Natalie Sherman. 2008. Microbiology : A Laboratory Manual (Eight Edition). Perason Benjamin Cummings, San Fransisco. Hal.134, 248-285, 585-588.

Cheeke. P.R. 2003. Actual and Potential Applications of Yucca schidigera and Quillaja saponaria Saponins in Human and Animal Nutrition. Procedding of The American Society of Animal Science. American Society of Animal Science.

Davis WW \& Stout TR. 2009. Disc Plate Method of Microbiological Antibiotic Assay. Applied and Enviromental Microbiology. Vol. 22 (4): 666-670.

Erawaty E, Dina Pratiwi, Mohammad Zaky. 2015. Pengembangan Formulasi Dan Evaluasi Fisik Sediaan Krim Ekstrak Etanol 70\% Daun Labu Siam (Sechium edule (Jacq.)Swatz). Farmagazine Vol. 3 No. 1.11-19.

Fitriansyah SN., dan Dolih G. 2014. Formulasi Dan Evaluasi Fisik Sediaan Krim Pelembab Dimethylsilanol Hyaluronate Dengan Penambahan Basis Nano Dan Fase Minyak Kelapa Murni. Indonesian Journal of Pharmaceutical Science and Technology. Vol $3(1)$.

Harbone JB. 1987. Metode Fitokimia Penuntun Cara Modern Menganalisis Tumbuhan. Terjemahan. Bandung: Institute Teknologi Bandung.

Kono SR., Paulina V.Y. Yamlean., Sri Sudewi. 2018. Formulasi Sediaan Obat Kumur Herba Patikan Kebo (Euphorbia hirta) Dan Uji Antibakteri Prophyromonas gingivalis. Pharmacon. Jurnal Ilmiah Farmasi. UNSRAT. Vol 7 (1): 37 - 46.

Kumar GS. 2007. Antimicrobial Effects of Indian Medicinal Plants Against Acne-inducing Bacteria. Tropical Journal of Pharmaceutical Research. Vol 6 (2) : 717 - 723.

Lapa Fernanda dan R., Cristina S. F., Cristiani. H.B., Fabiana C.M., Moacir G.P., Adair., S. S., and Maria C. A. M. (2007). Gastroprotective activity of the hydroalcoholic extract obtained from Polygala paniculata L. in rats. Journal of Pharmacy and Pharmacology. 59, 1413 - 1419

Lusiana, L. 2016. Uji Daya Hambat Ekstrak Euphorbia hirta Terhadap Bakteri Prophyromonas gingivalis secara in vitro. Fakultas Kedokteran UNSRAT. Manado.

Madduluri S., Rao KB., Sitaram B. 2013. In Vitro Evaluation of Antibacterial Activity of Five Indegenous Plants Extract Against Five Bacterial Pathogens of Human. In $J$ Pharm Sci. Vol 5(4) : $679-684$.

Margolis DJ., Bowe., Hoffstad O and Berlin JA. 2005. Antibiotic Treatment of Acne May Be Associated With Upper Respiratory Tract Infections. Arch Dermatol. 141 : 1132 1136.

Rijai. L. 2013. Potensi Herba Tumbuhan Balsem (Polygala paniculata Linn) Sebagai Sumber Bahan Farmasi Potensial. J. Trop.Pharm.Chem. Vol. 2 (2): 105 - 112.

Rowe, GR., P.J. Sheskey and S.C. Owen. 2006. Handbook of Pharmaceutical Excipients. London: Pharmaceutical Press.

Rusli D, Ade Arinia Rasyad, dan Putra Asa Nugraha. 2016. Formulasi Krim Klindamisin Sebagai Antijerawat dan Uji Efektrivitas Terhadap Bakteri Propionebacterium acne. Jurnal Ilmiah Bakti Farmasi, Vol1(2): 5-14

Septiana LB., Euis E., dan Taupik S. 2016. Uji Ekstrak Daun Beluntas (Pluchea indica L.Less) Terhadap Zona Hambat Bakteri Escherichia coli pathogen Secara In Vitro. Jurnal Pendidikan Biologi. Vol 4 (1): 64 - 68.

Simanjuntak, H.A dan Megawati Butar-butar. 2019. Uji Aktivitas Antifungi Ekstrak Etanol Umbi Bawang Merah (Allium cepa L.) Terhadap Candida albicans dan Pityrosporum ovale. Eksakta: Jurnal Penelitian dan Pembelajaran MIPA. Vol 4 (2): 91 -98

Simanjuntak, HA. 2020. Antibacterial Activity of Ethanolic Extract of Kitolod (Hippobroma longiflora) Leaf Against Staphylococcus aureus and Salmonella typhi. Asian Journal of Pharmaceutical Research and Development. 8(1): 52-54. 
Sudira, I. W., Merdana, I., \& Wibawa, I. 2011. Uji daya hambat ekstrak daun kedondong (Lannea grandis Engl) terhadap pertumbuhan bakteri Erwinia carotovora. Buletin Veteriner Udayana. Vol. 3(1), 45-50.

Sulastri A., dan Anis Y.C. 2016. Formulasi Masker Gel Peel Off Untuk Perawatan Kulit Wajah. Farmaka. Vol 14(3); $17-26$.

Suryani N., Devi N., dan Dimas DI. 2019. Aktivitas Antibakteri Ekstrak Batang Kecombrang (Etlingera elatior (Jack) R.M.Sm) Terhadap Bakteri Plak Gigi Streptococcus mutans. Jurnal Kartika Kimia. Vol 2 (1): 2329.

Tizziani T., Dalila V., Ana P.R., Lucas B.M., Pedro H.D.M.P., Elaine M. S.F., Moacir G.P and Ines M.C.B. (2017). Antitumor screening of crude extracts of ten medicinal plants of Polygala genus from Southern Brazil. Journal of Apllied Pharmaceutical Science. Vo. 7(10), $79-83$.

Wasitaatmadja, SM. 1997. Penuntun Ilmu Kosmetik Medik. Jakarta: UI - Press.

Wu T, Mengying H, Xixi Z, Ying Z, Tianfu Q, Siyi P, Xiaoyun X. 2013. A Structure Activity Relationship Study of Flavonoids As Inhibitors of E. coli By Membrane Interaction Effect. Biochimica et Biophysica Acta.2751-6.

Yaqin A. 2014. Potensi Antibakteri Ekstrak Etanol, Fraksi Etanol, Air dan Fraksi n-Heksan Daun Anggur (Vitis vinifera L.) terhadap Staphylococcus aureus dan Pseudomonas aeruginosa Multiresisten. Universitas Muhammadiyah Surakarta. 